\title{
Årsberetning 1975-1976
}

Årsmødet 1975 holdtes 29.-31. okt. på kursusejendommen Sandbjerg ved Sønderborg i forbindelse med et Grundtvig-seminar for unge teologer under ledelse af selskabets næstformand, professor Christian Thodberg. Der blev her forelagt en række arbejder om strukturen i Grundtvigs salmer og deres sammenhæng med hans samtidige prædikener. Pastor Helge Grell, Silkeborg, talte om begreberne "Skaberordet“ og „Billedordet“ i Grundtvigs tanker, og universitetslektor Fl. Lundgreen-Nielsen, København, om Grundtvigs ungdomsdigtning og poetik. Alle foredragene gav anledning til en livlig drøftelse.

Arbejdet med oversættelsen af et Grundtvig-udvalg til engelsk er fortsat, også efter at den amerikanske komité har trukket sig ud af arbejdet for at offentliggøre en egen oversættelse, der nu har set lyset på et amerikansk forlag. Vort arbejdsudvalg blev i februar 1976 enig om et udvalg på ca. 200 sider, der oversættes af M. A. Edward Broadbridge med støtte af Aarhus Universitets Forskningsfond. Som særlig sagkyndig i engelsk oversættelse af dansk litteratur har arbejdsudvalget optaget universitetslektor Niels Lyhne Jensen, der i mange år har undervist i dansk sprog og litteratur ved engelske universiteter og nu er ansat ved Aarhus Universitet.

Udgaven af Grundtvigs dagbøger ved professor Gustav Albeck mangler nu kun den sidste revision for at se dagens lys som led $\mathrm{i}$ Det danske Sprog- og Litteraturselskabs publikationer. Også et større arbejde af lektor Fl. Lundgreen-Nielsn er ved at blive afsluttet. Grundtvig-Studier har i år været meget længe om at finde bidragydere. De to redaktører træder til med hver sit bidrag. Desuden har redaktionen bedt selskabets hollandske medlem, pastor 
G. F. W. Herngreen gøre rede for sit arbejde for at introducere Grundtvig i Holland, hvor han hidtil har været næsten helt ukendt. Både fra dansk og tysk side er der lovet bidrag til de følgende årgange af Grundtvig-Studier.

Samarbejdet med Kirkeligt Samfund om kontoret i Vartov fortsætter. Men af finansielle grunde har selskabet måttet skifte trykkeri. Grundtvig-Studier 1976 udkommer først i begyndelsen af 1977. Til gengæld vil selskabets næste publikation følge kort efter og omfatte de ved Grundtvig-seminaret på Sandbjerg forelagte arbejder om strukturen i Grundtvigs salmer og prædikener i omarbejdet form. Selskabet har fra Konsul Jorck og Hustrus Fond modtaget en gave på $5000 \mathrm{kr}$. foruden den sædvanlige støtte fra Carlsen-Langes Legatstiftelse og Undervisningsministeriet.

William Michelsen. 